\title{
The developmental history of mental disorder in old age
}

\author{
An international perspective
}

\author{
John R. RoBInson, Consultant Psychiatrist, Littlemore Hospital, Oxford
}

A worldwide demographic shift towards old age is being accompanied by a corresponding increase in the number of old people presenting with psychiatric disorders, and traditional systems are unable to cope with the problem.

Referring to the chaotic development of industrial England during the Napoleonic period, Trevelyan ${ }^{1}$ comments, "Man had acquired formidable tools for refashioning his life before he had given the least thought to the question of what sort of life it would be well for him to fashion". However, reforms were on their way and, combined with advances in public health, they ensured that many of the children of Victorian and Edwardian parents would live into old age, despite the ravages of two world wars. This improved expectation of life has continued and, in the past 150 years, it has approximately doubled from 40 to 80 years. ${ }^{2}$ The traditional ways of coping with the health problems of old people became quite inadequate, and this resulted in the establishment of specialised geriatric services after the Second World War, and of psychogeriatric services in the 1960s.

Not only has the proportion of people aged over 65 years in Britain increased to $15 \%$ but currently there is a disproportionate increase, within this age group, of the very old. According to Grundy ${ }^{3}$ "... the age group of people over 80 is growing more rapidly than any other". There are two and a half times as many people aged over 85 as there were 30 years ago, and, between 1970 and 1980, life expectation at the age of 85 increased by about six months. ${ }^{4}$ This changing age structure of the elderly population in Britain will give an increase in the number of cases of dementia of $17.2 \%$ between 1983 and the year $2001 .^{5}$ Moreover, during the past century and a half, the world population has increased from one to five billion. The whole world will be challenged by this unprecedented phenomenon.

Psychiatrists who specialise in the mental disorders of old age are responding by sharing their knowledge and experience internationally, not only through the established journals and conferences, but also through new initiatives such as the geriatric psychiatry section of the World Psychiatric Association and the new International Journal of Geriatric Psychiatry.

\section{The study}

The present comparative survey has the following aims: to examine the traditional role of old people in a number of societies, internationally; to observe the effect upon this role and upon their mental health of changes in these societies, including demographic developments; and to see what measures are being taken to solve the problems which arise.

Relevant information was recorded during the course of a four month planned tour of India, Nepal, Hong Kong, The Philippines, Australia, New Zealand, and the United States of America, between 29 October 1987 and 26 February 1988. Background observations and information gained from informal contacts were supplemented by 20 professional visits, ten of which were to university departments concerned with the psychiatry of old age.

\section{The findings \\ Nepal}

The Himalayan Kingdom of Nepal is unique in being a Hindu state. Over thousands of years the people who came to live here combined their ingenuity with the wisdom of nature to farm the terraced slopes, to fish the mountain waters, and to live in harmony with their environment. This is a pre-industrial agricultural society in which the vast majority of the population live in the country, where little has changed, and the traditional role of old people has been maintained. They are the respected elders of the community, heads of the family, and owners of the land. They are looked up to as sources of wisdom, information, and technical knowledge, and they hand on the cultural and religious traditions. They continue to work on the land and in the home, they care for the children, and guide the generations. Sons are obliged to look after their parents in old age.

Nepal has a young population, with only about $3 \%$ out of 14 million over the age of 65 years. The average expectation of life is in the region of 45 years. Important causes of death are such infections as typhoid fever, hepatitis, cholera, and tuberculosis, and respiratory disease associated with smoke from 
the wood fires in homes which have no chimneys; malnutrition also plays a part. Some of the main psychiatric problems arise out of conflicts in families, over-crowded conditions and financial matters relating to land. Psychiatric symptoms tend to present as physical complaints and there is a stigma attaching to mental illness. If old people have psychiatric problems the son will present this to the doctor. There are no significant mental hospital facilities and what exists is used by the poor, who have nothing to lose. In some cases old people are left to fend for themselves when their sons move out of the home in search of better prospects.

\section{India}

In India, an ancient land of great beauty and of marked contrasts, the traditional role of old people, which is similar to that in Nepal, is largely maintained. In spite of increasing urbanisation the great majority of the population, and $70 \%$ of old people, live in the villages. Out of a population of 700 million, only about $3 \%$ are over the age of 65 years. The average expectation of life is around 55 years. Old people are contained within the family and senile dementia is regarded as part of getting old. ${ }^{6}$

However, there are problems, and many of them are associated with the transition from a preindustrial to an industrial society, from a subsistence economy to a waged economy.

When young people migrate to the towns, the old folk may be left in the country, sometimes with inadequate support, or they may follow their children to face an uncertain future in the city; in either case they are likely to have to work too hard and too long to eke out a meagre living. In the industrial world, status depends more on educational and technical skills than upon age, traditional know-how, hierarchy, and caste. Young people become more independent, old values are less highly regarded and, as the son takes charge of his family, the role of the old ones becomes eroded and less clear with consequent tension, frustration, and depression. The smaller family is less in need of a grandparent to look after the children, and when the younger women go out to work they are no longer available to care for ageing, ailing parents. Social security, medical services, and provision for institutional care are nonexistent or quite inadequate; there is no substitute for the missing family care. Country ways are not always adaptable to the crowded conditions of the towns, though the outward appearance of slum dwellings can belie their interior good order. The fate of old people depends upon the balance of their economic state, their physical and emotional health, and their social situation. They may be driven to sleep on the pavements where they wander, though often they would prefer to sleep in a corridor rather than in an institution. On the other hand, they may be fortunate enough to find a place in a home such as the one run by the Little Sisters of the Poor in Bombay, where an atmosphere of activity and happiness is pervasive, and where the standard of care is of the highest order.

\section{The Philippines}

The Philippines became a Spanish possession following their discovery by Magellan in 1521. They were ceded to the United States in 1898 and, after being overrun by the Japanese during the Second World War, they became an independent republic in 1946. Spanish cultural influence remains strong. The predominantly Catholic population of 56 million is distributed among 7,000 tropical islands, and 70\% of the people live in rural areas. The traditional role of old people, which parallels that in Nepal and India, and includes the gratitude of their children, is very largely preserved. The family structure in which most of them live, partly because of housing shortage, is strong and close. Interest centres on the children, and women tend to stay at home; though in Manila they seek university education.

The population is a young one with only $2.8 \%$ over the age of 65 years, and $60 \%$ are under the age of 25 years. The average expectation of life is 65 years. Significant causes of death are typhoid fever, diarrhoea, tuberculosis, and cardiovascular disease; and also malnutrition - in spite of the fertility of the land, $60 \%$ of the population live below the poverty line. There are 70 homes for old people, mostly private or religious, and they have under 1,000 residents. These people were often migrants into the cities, impoverished and without relatives, features which evoke a certain dread of residential care. Although health care in the city is good, health facilities in the rural areas are lacking. Psychiatric problems are contained in the community and people seek the help of faith healers. However, in the department of neuropsychiatry at the University of Santo Tomas there is an increasing problem of, and interest in, referrals of elderly people.

\section{Hong Kong}

In Hong Kong, the role of old people in society remains basically true to the family-centred Chinese tradition, despite an atmosphere of hectic international commerce. The extended family has been largely replaced by the nuclear family, but the old folk continue to be included and filial piety remains the rule.

The expectation of life has increased to 78 years for females and 72 years for males. Moreover, the rate of increase in those aged over 70 years is nearly twice as rapid as that of all people aged over 60 years. These features, combined with a falling birth rate, are producing an old population where, out of the 5 million 
inhabitants, the proportion aged over 65 years is moving from $8 \%$ towards $10 \%$.

Old people often have to continue working in order to live and to help meet family expenses, though a small retirement pension is about to be introduced. When they become infirm, help is less frequently available because of smaller families and women going out to work. There are a considerable number of middle-aged single people coming in to Hong Kong from mainland China and they will lack support when they get old. Small apartments in high rise buildings make it difficult to cope with a confused old person. Not infrequently old folk are left at the hospitals, and to release the beds in the psychiatric sector is a problem. The introduction of a legal obligation for children to take care of their parents is under consideration. Suicide in old age is common.

Official policy aims at promoting the care of old people in the community. Medical care is unevenly distributed and private practice means that a large percentage of the available doctors are attending to a small proportion of the population. Those interested in the psychiatry of old age are confronted by formidable problems relating to the development and integration of social, medical, and psychiatric services in the face of a growing elderly population.

\section{Australia}

No doubt the pioneering tradition of Australians determines their role in old age, which is one of vigorous independence. Multi-ethnic cultural factors play their part. The Aboriginal people used to go off into the bush to die when they grew old; though, before their 40,000 year old lifestyle was disrupted by the introduction of European ways and diseases in 1788, their nomadic existence appears to have been a healthy one. ${ }^{8}$

The average expectation of life at birth is 73 years for males and 80 years for females; though that for the Aboriginal people is 20 years less. Between 10 and $11 \%$ of the population are aged over 65 years, and this will rise to $12 \%$ by the year 2001 , and to $16 \%$ by 2021. ${ }^{9}$

The nuclear family is the rule and although old people tend to live independently the family remains involved. Granny flats and purpose-built complexes for the elderly are a feature, and, for old people who become physically or mentally dependent, there are private nursing homes which give a variable quality of care.

The Richmond Report of 1983 recommended the promotion of community psychiatry and much has been achieved in this direction, though, with the psychiatry of old age, much still needs to be done, and progress is dependent on government policy. The few psychiatrists specialising in the problem of old age find it difficult to meet regularly because of the great distances involved, but interest in the speciality is growing and a specialist section in the Royal Australian and New Zealand College of Psychiatrists is being planned. Research is getting underway and academic appointments are being made.

In Western Australia, the new lodges created on the closure of Swanborne psychiatric hospital, and associated with general hospitals, are impressive; and in New South Wales the first of 27 planned 16 bedded CADE (confused and disturbed elderly) units has been opened. Physical facilities are enviable as are nursing ratios. Patients with senile dementia tend to be referred to the geriatricians unless there are marked psychotic features, and the pressura on inpatient resources does not appear to be so great as in Britain. The distribution of services throughout the country appears to be variable. The nature of private practice and the large distances involved produce difficulties in creating local, integrated, community based, psychogeriatric services.

The Australians are facing a demographic challenge similar to that in Britain after the Second World War, but they are confronting it with an enthusiasm informed by the British experience.

\section{New Zealand}

Captain James Cook claimed the isolated, mountainous, and volcanic istlands of New Zealand for the British Crown in 1769. However, organised settlement, mainly by people from the British Isles, did not begin until 1840 , following the signing of the treaty of Waitangi with the Maoris, who had already lived there for over 500 years. Out of the present total population of some 3.5 million, about $10 \%$ are over the age of 65 years. The Maori component is younger, with little more than $2 \%$ over the age of 65 years among the 300,000 or so whose origin is half or more Maori. Whereas the average expectation of life, overall, is about 75 years, for the Maoris it is considerably less. Accounting for their earlier deaths are such problems as obesity, diabetes, and vascular incidents, and they are less often immunised against disease. Access to medical services is impeded by their perceptions, and by the time old folk come into hospital they are often seeking confirmation that they are dying - death is perceived as a journey rather than as a failure. Maori old folk, the 'kaumatua' are revered and kept in the families, the 'tohunga', who is a specialist in healing, may be consulted. Most New Zealanders live in nuclear families and they rally round when old folk are in need.

New Zealand was the first country in the world to introduce the Old Age Pension, which it did in 1898. Present policy promotes community care of the elderly in the family, where the basic responsibility 
lies, or, if this is not available, through community and religious organisations. Where such resources are unable to make suitable provision, the onus falls on the state through the medium of the hospital boards. The Committee for Health Care of the Elderly plans an integrated geriatric and psychogeriatric service such as is established at Dunedin. Mental hospital populations have been greatly reduced over recent years. Psychogeriatric assessment units are developing their outreach into the community where multi-disciplinary assessments are made in the patients' home, and where consultative and supportive services are provided.

\section{The United States of America}

The traditional role of old people in the USA varies according to the multitude of their ethnic origins as well as their present circumstances. The ageing of the population is $\mathbf{4 0}$ years behind that in Northern Europe but is proceeding in the same demographic direction with, currently, $12 \%$ of the population of 242 million over the age of 65 years, ${ }^{10}$ and with an average expectation of life at birth in the 70 s. Gerontology is already a well established subject in American universities; and a major boost to research arose out of the 1971 White House Conference on Ageing. Hotels and apartments occupied largely by old people are a feature of such places as Miami Beach; village communities of elderly citizens have been established; and in the cities large blocks of purpose-built flats are designated for their use.

One of the main problems for the psychiatry of old age appears to be that it is so often hospital-based and dependent on what is financially viable; there is no sense of looking after the patient in all settings. Medicare pay $80 \%$ of the medical fees for the elderly and the other $20 \%$ will be covered by insurance, and, for the poor, Medicaid is available. Private hospitals are eager to capture this growing market and strive to provide attractive facilities and high technology, with a consequent duplication of services. There is considerable disparity between the quality of care available in a university department or in a private hospital and that in a general hospital to which poor people are likely to go; but in some cases prestigious teaching hospitals are taking over their poorer counterparts. In some instances, where substantial hospital fees are available, the motivation is not to keep people in the community, but to admit them to hospital, and, in other circumstances, insurance companies tend to pressurise for rapid patient discharge. Considerable moves are being made to overcome such obstacles and to develop an appropriate and comprehensive psychogeriatric and geriatric service. Commercial enterprises are also seeing that it is expedient, in the interest of a contented and efficient work force, to help their employees to care for elderly relatives.

The concept of 'Alzheimer dementia' has caught the public imagination and this groundswell of interest helps to produce contributions from many sources for research. In addition to those which are already established, new academic departments concerned with the psychiatry of old age are being founded, often under the direction of an experienced senior psychiatrist, for training younger doctors in this speciality. Evaluation teams for assessment are likely to consist of a psychogeriatrician, a geriatrician, a social worker, a psychologist, and a clinical nurse specialist; and home visits, work with the family, and support groups, are regarded as important, in addition to the clinical and technological work up.

Current research addresses many aspects of the problem and some of the projects are noted below. Epidemiological prospective studies include a longitudinal study of several thousand elderly retired people in Florida aimed at examining the nature of ageing; an Alzheimer Dementia Research Clinic, established in 1980, screens large numbers of referrals, with follow-up of selected cases; participation in an Ageing and Dementia Research Programme is invited, and a full work-up of each case is carried out by a multidisciplinary team, and the aim is to delineate between normal ageing and dementia; other, community-based follow-up studies of Alzheimer dementia, unbiased by selection, aim at examining risk factors, outcome, and relationship to other disorders. Basic research is being carried out to enable anticipation and treatment of Alzheimer dementia; non-invasive technology is being extensively used. Health psychology is a growing subject. Different types of management are being examined, for instance: physical rehabilitation and a psychological approach to depression and disability in the elderly are being compared; drug-free and restraintfree management are being considered. Research also involves pharmacology and biochemistry, chromosomal studies, and tissue replacement possibilities. The publication of the new American Journal of Alzheimer Dementia Research has just been announced.

\section{Comment}

An attempt has been made to look at the role of old people, in health and disorder, in seven very different countries. In pre-industrial societies their role has developed gradually over thousands of years, and those who survive into old age are in an established state of equilibrium with the populations of which they are the elders and for which their importance is not in doubt. As such societies become 
industrialised, this state of equilibrium is seen to be disrupted. The role of old folk becomes less clear, with consequent insecurity, frustration, depression, and poverty. Post industrial societies have already been challenged by this problem, compounded by the new phenomenon of an ageing population. As traditional ways of doing things pass into history, new arrangements of societies attempt to restore a satisfactory role to their older members. This multifaceted problem is studied in academic institutions, and research includes an attempt to rediscover the strengths of past relationships. Clearly these three stages in society have much to learn from each other, ranging from traditional wisdom to molecular biology.

The majority of old people appear to be satisfactorily integrated into all three societies, but the proportion who are not represent a large and increasing number. Referring to the world's population, Beeson ${ }^{11}$ remarks, "In 1970 there were 291 million people over the age of 60 and, of these, 26 million were over 80 . The corresponding figures for the end of the century are expected to be in the region of 600 million and 58 million respectively - with $20 \%$ or more of the over 80 s being demented". This is to say nothing about all the other causes of mental disorder in old age. The aim should be to prevent such disorders and, for this, besides specific measures, there needs to be a social context of constructive attitudes towards getting old.

Such a context emerged out of the Asian Regional Conference on Active Ageing in 1982. The conference addressed the situation of elderly people in Asian countries under four headings: economic security; health; education and leisure; and spiritual dimension. The general conclusion was: to prevent premature ageing; to promote the attempts of families to care for their old folk; and to institute alternative possibilities where necessary. The anticipation of problems by the development of insurance and pension schemes, by health education, by education for leisure, and by encouraging personal adaptability while strengthening useful cultural traditions, featured prominently. 'Active Ageing' aims at a state of wellbeing and fulfilment, taking advantage of opportunities of every kind, cultural and material, and with the participation of the aged in policy decisions for the aged. ${ }^{12}$

\section{Acknowledgements}

The author wishes to thank all the people, too numerous to name, from whom he received help during this tour, and especially the following professional contacts, for introduction to many of whom he is indebted to Professor Tom Arie, and the members of their teams: Mr O. Carton, Professor C. N. Chen, Dr E. Chiu, Dr K. G. Desai, Dr C. Duncan, Dr P. Downey, Dr S. Galhenage, Fr F. Gomez, O. P., Dr M. Gunn, Professor B. Gurland, Professor L. F. Jarvic, Professor F. A. Johnson, Dr V. Jones, Rosamma Joseph, Mrs C. Lobo, Professor E. Pfeiffer, Professor P. V. Rabins, Professor B. Reisberg, Dr K. J. Shah, Dr J. Snowdon, Dr R. T. Walker and Dr S. Williams.

He also wishes to express his appreciation to the Oxford Regional Study Leave Committee; and to his wife whose encouragement and organisational ability made the tour possible.

\section{References}

'Trevelyan, G. M. (1942) Illustrated English Social History: 4, London: Pelican Books (1964).

${ }^{2}$ Hayflick, L. (1982) Biological aspects of human aging. British Journal of Hospital Medicine. April 1982, 366-375.

${ }^{3}$ Grundy, E. (1987) Community care for the elderly. British Medical Journal, 294, 626-629.

4 - (1987) Mortality and morbidity among the old. British Medical Journal, 228, 663-664.

${ }^{5}$ INEICHEN, B. (1987) Measuring the rising tide. How many dementia cases will there be by 2001 ? British Journal of Psychiatry, 150, 193-200.

${ }^{6}$ Desal, K. G. (ed.) (1982) Aging in India. Bombay: Tata Institute of Social Sciences.

${ }^{7}$ Social Research Centre University of Santo Tomas (1982) Editor \& Publisher. The Elderly of Asia, Manila.

${ }^{8}$ Holliday, J. (1987) People been dying. Oxford Medical School Gazette, XXXVIII, 33-35.

${ }^{9}$ Williams, S. (1986) Geriatric psychiatry in Australia. International Journal of Geriatric Psychiatry, 2, 67-69.

${ }^{10}$ LANCET (1986) Geriatrics and the USA. Lancet, i, 133-134.

${ }^{11}$ BeEson, J. (1983) Dementia: biological solution still a long way off. British Medical Journal, 287, 926-927.

${ }^{12}$ Di FilıPPo, E. Opera Pia International for Active Aging. In The Elderly of Asia. Manila: Social Research Centre, University of Santo Tomas. 